\begin{tabular}{|c|c|c|}
\hline institute & $\begin{array}{l}\text { CARADDE: Jurnal Pengabdian Kepada Masyarakat } \\
\text { https://journal.ilininstitute.com/index.php/caradde } \\
\text { Volume 2 | Nomor 1 | Agustus | 2019 } \\
\text { e-ISSN: 2621-7910 dan p-ISSN: 2621-7961 } \\
\text { DOI: https://doi.org/10.31960/caradde.v2i1.82 }\end{array}$ & $\begin{array}{l}\text { IUiN } \\
\text { CARADDE }\end{array}$ \\
\hline
\end{tabular}

\title{
Peningkatan Partisipasi Petani Dalam Pengendalian Hama Dan Penyakit Tanaman Kakao Berbasis Bahan Alam
}

\author{
La Ode Santiaji Bande ${ }^{1}$, La Ndia $^{2}$, Asnia $^{1}$, dan La Ode Alwi ${ }^{1}$
}

\author{
Keywords: \\ bahan alam; \\ pesitsida nabati; \\ hama; penyakit tanaman; \\ kakao

\section{Corespondensi Author} \\ La Ode Santiaji Bande \\ Hama dan Penyakit Tanaman, \\ Program Studi Proteksi Tanaman \\ Alamat: Perumahan Dosen UHO, \\ Blok R/9 Kampus Baru UHO- \\ Kendari \\ Email: 1d_alwi@yahoo.co.id
}

\section{History Artikel}

Received: Januari-2019;

Reviewed: April-2019

Accepted: April-2019

Published: Juni-2019

\begin{abstract}
Abstrak. Pengabdian ini bertujuan untuk meningkatkan partisipasi masyarakat dalam pengendalian hama dan penyakit tanaman kakao berbasis bahan alam. Waktu pelaksanaan pengabdian selama 1 (satu) bulan di Desa Amohalo Kecamatan Konda Kabupaten Konawe Selatan dengan metode ceramah, sosialisasi, pelatihan dan tes pemahaman setelah dan sebelum pengabdian dilaksanaknakan. Hasil pengabdian menujukkan bahwa petani kakao di lokasi pengabdian belum memanfaatkan bahan alam sebagai pengendali hama dan penyakit tanaman kakao. Kondisi ini disebabkan adanya rendahnya pemahaman masyarakat serta tidak mempunyai keterampilan dalam perakitan bahan alam sebagai pestisida nabati yang berfungsi sebagai pengendali hama dan penyakit tanaman kakao. Disisi lain hasil pengandian pengabdian menujukkan pula terjadinya peningkatkan pemahaman dan keterampilan petani dalam pemanfaatan bahan alam serta keterampilan dalam membuat produk bahan alam sebagai pestisidan nabatai dalam pengendalian hama dan penyakit tanaman kakao
\end{abstract}

(i) This work is licensed under a Creative Commons Attribution

4.0 International License

\section{PENDAHULUAN}

Kabupaten Konawe Selatan sebagai wilayah daratan yang banyak ditemukan berbagai biodiversiti yang mempunyai banyak fungsi diantara sebagai penganggulanga hama dan penyakit. Namun dalam banyak realitas potensi-potensi ini belum dilakukan oleh masyarakat dalam upaya penanganan hama dan penyakit tanaman kakao (Ardana et al, 2010 dan Birgit, 1995). Berbagai faktor, yang dapat menyebabkan masyarakat atau petani kakao belum menggunakan berabagai jenis bahan alam tersebut, diantaranya adalah: (i) ketidaktahuan masyarakat akan fungsi bahan alam sebagai bahan penanggulangan hama dan penyakit tanaman kakao, (ii) keterbatasan informasi terhadap fungsi bahan alam sebagai tindakan cepat dini dalam penanggulangan hama dan penyakit tanaman kakao; (iii) obesisi masyarakat atau petani kakao bahwa pengendalian hama dan penyakit tanaman kakao tidak lain, hanya dengan bahan kimia.

Kampus merupakan bagian dari integral pembangunan berkelanjutan adalah tranfer ilmu pengetahuan atau knowlegde transfers, baik melalui pendidikam dan pengajaran maupun melalui penelitian dan pengabdian kepada masyarakat. Universitas Halu Oleo (UHO) sebagai salah salah satu Perguruan Tinggi yang memiliki komitmen dalam kegiatan Tridharma Perguruan Tinggi, dan salah satu program pengabdian kepada masyarakat terintegrasi KKN Tematik. Oleh karena itu, pengabdian kepada masyarakat terintegrasi KKN Tematik merupakan sebuah 
sistem manajemen atau program UHO dalam transfer ilmu pengetahuan kepada masyarakat dengan melibatkan beberapa dosen yang profesional (sesuai bidangnya) serta mashasiswa tingkat akhir. UHO memandang bahwa konsep pengabdian kepada masyarakat terintegrasi KKN Tematik merupakan solusi yang paling tepat dalam menjawab dan mengatasi permasalahan masyarakat terutama terkiat dengan pengendalian hama dan penyakit tanaman kakao.

Lokasi pengabdian di laksanakan pengabdian kepada masyarakat terintegrasi KKN Tematik dilaksanakan di Desa Amohalo Kecamatan Konda Kabupaten Konawe Selatan dengan pertimbangkan bahwa lokasi tersebut, merupakan wilayah pengembangan pertanian baik pertanian tanaman pangan, perkebunan maupun tanaman hortikultura dengan luas mencapai 1.021 hekatra atau $83,21 \%$ dari total luas wilayah Desa Amohalo (Alwi, 2018).

Selain potensi luasan tersebut, Desa Amohalo memiliki berbagai sumberdaya nabati yang dapat berfungsi sumber pestisida alami dan pupuk organik dalam peningkatan produktivitas pertanian. Namum demikian sesuai dengan hasil penelitian Alwi (2018) bahwa petani di Desa Amohalo masih mempunyai ketergantungan pupuk anorganik. Sehingga bila terjadi kelangkaan pupuk anorganik berimplikasi pada peningkatan harga obat-obatan/pupuk yang berdampak pada penurunan daya beli petani. Peningkatan harga pupuk anorganik berdampak langsung terhadap penurunan pendapatan dari sector pertanian mencapai $34,23 \%$ pertanian (Alwi, 2018).

Dengan ketersedian sumberdaya nabati, sebenarnya permasalahan obatobatan dalam penanggulangan hama dan penyakit tidak menjadi suatu permasalahan dalam peningkatan produktivitas pertanian di Desa Amohalo Kecamatan Konda Kabupaten Konawe Selatan. Dengan menggunakan pemanfaatan sumberdaya nabati dalam penangulangan hama dan penyakit tanaman dapat menjamin kestabilan produktivitas pertanian dan pendapatan petani serta memastikan kebelanjutan ketersediaan obatobatan/pupuk dalam meningkatkan produktivitas pertanian. Hanya yang menjadi persoalan adalah keterbatasan pengetahuan dan keterampilan petani dalam memanfaatkan sumberdaya nabati tersebut.

Berdasarkan fenomena tersebut, maka melalui Program Tematik akan mengambil peran dalam pembangunan sosial ekonomi masyarakat terutama dalam pengendalian hama dan penyakit berbasis bahan alam melalui Program Pengabdian Dosen Terintegrasi KKN Tematik. Desa Amohalo Kecamatan Konda merupakan salah satu Desa yang ada di Kabupaten Konawe Selatan

\section{METODE}

Waktu pelaksanaan pengabdian dosen terintegrasi KKN Tematik Peningkata Partisipasi Peustani dalam Penanggulangan Hama dan Penyakit Tanaman Kakao Berbasis Bahan Alam dilaksanakan selama 1 (satu) bulan yakni Juli - Agustus 2018 yang bertempat Desa Amohalo Kecamatan Konda Kabupaten Konawe Selatan.

Pelaksanaan Pengabdian Dosen KKN Temati Peningkata Partisipasi Peustani dalam Penanggulangan Hama dan Penyakit Tanaman Kakao Berbasis Bahan Alam, dilaksanakan beberapa tahap, yakni:

Sosialisasi pelaksanaan pengandaliian pada tingkat masyarakat Desa Amohalo tentang berbagai jenis bahan alam yang dapat digunakan untuk menanggulangi hama dan penyakit tanaman kakao. Kegiatan sosialisasi ini dilaksanakn sebelum kegiatan pengabdian terintegrasi KKN Tematik dilaksanakan. Setelah penentuan lokasi dan sosialisasi program pengabdian dilaksanakan, maka diterikan dengan pembekalan mahasiswa tentang Penanggulangan Hama dan Penyakit Tanaman Kakao Berbasis Bahan Alam sebelum turun di lapangan. Setelah mahasiswa ke lapangan pertama yang dilaksanakan adalah melaksanakan tes pemahaman tentang bahan alam sebagai pengendali hama dan penyakit tanaman kakao. Tes dilaksanakan dengan tujuan untuk mengetahui sejauhmana pemahaman masayarakat dalam menggunakan bahan alam sebagai obat dalam penaggulangan hama dan penyakit tanaman. Berdasarkan hasil tes, ternyata ditemukan adanya keterbatasan pengetahuan, pemahaman dan kegterampilan petani, maka dilakukan platihan pada masyarakat tentang pembuatan 
pestisida nabati berbasis bahan alam yang meliputi: ubi gadung dan komba-komba, serta pelatihan pembuatan MOL dari buah maja sebagai pemacu pertumbuhan. Setelah adanya pelatihan dan terjadinya peningkatan pemahaman dan keterampilan dalam pemanfaatan bahan alam sebagai pestisida nabatai, maka diteruskan dengan sosialisasi pengaplikasi pestisida nabati. Kegiatan ini dilaksanakan dengan tujuan untuk meningkatkan pemahaman masyarakat dalam pemanfaatan bahan alam sebagai pestisida nabati dalam penganggulangan hama dan penyakit tanaman.

\section{HASIL DAN PEMBAHASAN}

\section{Pemahaman Masyarakat tentang Bahan Alama sebagai Pengendali Hama dan Penyakit Tanaman Kakao}

Pemahaman tentang bahan alam sebagai pengendali hama dam penyakot tanaman kakao merupakan modal dalam mempertahankan produktivitas usahatanai kakao. Sesuai dengan hasil tes pemahaman yang dilakukan pada 73 orang petani kakao di Desa Amohalo Kecamatan Konda Kabupaten Konawe menunjukkan bahwa pemahamaan yang rendah terhadap bahan alam sebagai pengendali hama penyakit tanaman kakao. Dimana terdapat $89 \%$ dengan kategori pemahahaman yang sangat rendah serta $11 \%$ kategori pemahaman yang rendah. Kondisi ini menunjukkan bahwa petani kakao di daerah tersebut tidak mengetahui tentang fungsi bahan alam sebagai pengendali hama dan penyakit tanaman

\section{Pelatihan Pembuatan pestisida nabati dari umbi gadung dan komba-komba}

Proses pembuatan pestisida nabati yang berbahan umbi gadung dan kombakomba dimulai dengan mengumpulkan bahan seperti ubi gadung dan tanaman kombakomba. Bahan ini dipilih dikarenakan mudah di dapat dilokasi pengabdian dan kondisi hutan masih terjaga sehingga bahan alam seperti ubi gadung dan tanaman kombakomba masih melimpa. Bahan lain dalam pembuatan pestisida nabati yaitu deterjen 15 gram dan air bersih 15 liter. Fungsi detergen dalam pembuatan pestisida nabati adalah sebagai perekat agar pestisida nabati dapat menempel pada permukaan daun tanaman yang diaplikasikan menggunakan pestisida nabati.

Langkah selanjutnya dengan mencuci dan mengupas kulit umbi gadung, pengupasan dilakukan sebaiknya tidak terlalu tebal agar kandungan yang terkandung dalam kulit ubi gadung tidak terbuang. Setelah dikupas, selanjutnya diparut dan diperas untuk diambil sarinya. Setelah sarinya telah diambil maka selanjutnya mencincang tanaman komba komba. Setelah semua bahan siap selanjutnya mencampur semua bahan seperti ubi gadung, tanaman komba-komba, deterjen dan air dalam satu wadah. Setelah didiamkan selama 24 jam, bahan siap di aplikasikan pada tanaman pertanian.

\section{Pembuatan MOL Menggunakan Buah Maja}

Kesadaran masyarakat untuk mengkonsumsi produk sehat dan alami, bebas pestisida kimia maupun mulai tumbuh. Sumber pestisida alami dan pupuk organik mulai tergali. Terlebih, keduanya mudah diperoleh bisa dari bahan-bahan sekitar lingkungan seperti limbah rumah tangga. Untuk membuat pupuk organik perlu mikroorganisme lokal (MOL) sebagai starter. MOL ini berfungsi mengurai bahan organik menjadi unsur hara yang diperlukan tanaman. Ternyata, bahan membuat MOL pun ada di sekitar, seperti buah maja, yang selama ini tidak dimanfaatkan dan terbuang begitu saja. Tanaman maja banyak ditemukan di Asia Selatan, Asia Tengah, termasuk Indonesia. Tanaman ini tumbuh di dataran rendah hingga ketinggian 500 meter atas permukaan laut. Maja bisa tumbuh di lahan basah seperti rawa-rawa maupun kering. Buah maja mengandung nitrogen tinggi, memiliki zat pengatur tumbuh baik untuk tanaman,

Untuk membuat MOL maja, pertama memilih buah tua atau masak dengan ciri-ciri jika dipegang tempurung terasa keras. Warna kulit buah dari hijau tua menjadi lebih terang. Daging maja mengkal pahit. Jika masak manis. Gula di dalamnya akan memudahkan proses fermentasi. Lalu, maja dibelah menjadi dua bagian, ambil daging buah dan lumatkan memakai tangan, sendok, atau blender. Hatihati saat membelah dengan pisau karena kulit licin dan keras.

Setelah lumat masukkan kewadah ember 25 liter. Isi wadah dengan air bekas cucian beras kira-kira 18 liter, 3 buah maja 
dan 500 gram gula merah kemudian ditutup. Penutup yang digunakan harus memiliki lubang selang yang berguna sebagai sirkulasi udara. Wadah tidak di isi sampai penuh untuk menyisakan ruang udara pada wadah. Fermentasi menghasilkan gas. Jadi, penutup wadah( setiap hari harus dibuka sebentar untuk mengeluarkan gas, lalu ditutup lagi. Proses itu diulangi sampai larutan 10-14 hari, dan siap digunakan.

$$
\text { Larutan bisa disiramkan }
$$

menggunakan sprayer atau siram begitu saja ke tanaman. Dosisyang digunakan 1 liter MOL untuk lima liter air. Kala menunjukkan perbedaan nyata pada pertumbuhan tanaman, lanjutkan pemupukan. Pupuk cair menggunakan maja bagus buat merangsang pertumbuhan tunas.

\section{Sosialisasi Pengaplikasian Pestisida Nabati}

Akhir-akhir ini meluasnya perubahan ekosistem tumbuhan mengakibatkan meledaknya populasi Organisme Pengganggu Tanaman (OPT). Tingginya populasi OPT dan penyakit tumbuhan dapat mengakibatkan penurunan tingkat produksi tanaman. Untuk mengatasi masalah tersebut penggunaan pestisida kimia sintetik menjadi jalan alternatif bagi petani (Madry, 1994 dan Pakih, 1999)).

Pestisida kimia sintetik yang sering digunakan adalah golongan insektisida. Selain banyak beredar di pasaran, pestisida ini dapat bekerja cepat untuk menekan laju populasi hama (Karmawati, 2010). Penggunaan pestisida kimia sintetik sebenarnya berdampak negatif terdahap ekosistem, seperti pencemaran air, mengeraskan tanah, membunuh musuh alami dari hama itu sendiri bahkan meracuni manusia (Lim, 1992, Chamber, 1992 dan Lyra, 1990). Apalagi jika penggunaannya secara terus menerus dan dalam jangka panjang.

Karena bahaya yang ditimbulkan, maka pemerintah Indonesia mengeluarkan kebijakan tentang perlindungan tanaman dengan menggalakkan program Pengendalian Hama Terpadu (PHT). Kebijakan ini tertuang dalam Peraturan Pemerintah No. 6 tahun 1995 menyatakan bahwa pemanfaatan agens pengendali hayati atau biopestisida termasuk pestisida nabati sebagai komponen utama dalam sistem PHT.

Peraturan tersebut akhirnya menjadi latar belakang munculnya pestisida nabati. Sesuai namanya, pestisida nabati ini berbahan dasar tumbuhan. Kini pestisida nabati menjadi terobosan untuk membasmi hama dan penyakit tumbuhan. Selain itu juga berfungsi sebagai pupuk yang menyuburkan tanaman dan menjaga keseimbangan ekosistem alam.

Pengendalian OPT dengan menggunakan pestisida nabati perlu dikembangkan dan ditindaklanjuti. Hal ini penting karena cara tersebut merupakan usaha pengendalian yang sesuai dengan program PHT. Pestisida nabati sebenarnya lebih murah, aman, mudah dibuat dan ramah lingkungan.

Sebagai bentuk dukungan terhadap kebijakan tersebut perlu adanya sosialisasi pada masyarakat terutama Desa Amohalo Kecamatan Konda guna untuk meningkatkan kesadaran masyarakat akan pentingnya menggunakan bahan alam sebagai pestisida.

Kegiatan sosialisasi di awali dengan mewawancarai setiap warga atau kepala keluarga atau petani Desa Amohalo guna untuk mendapatkan data mengenai tanaman yang dibudidayakan oleh masyarakat dan keluhan hama dan penyakit yang dihadapi oleh masyarakat.

Setelah semua data terkumpul, langkah selanjutnya yaitu dengan melakukan pertemuan pertama dengan warga guna untuk mengsosialisasikan tentang penggunaan pestisida nabati guna untuk mengendalikan penyakit blendok pada tanaman jeruk dan hama PBK pada buah kakao. 

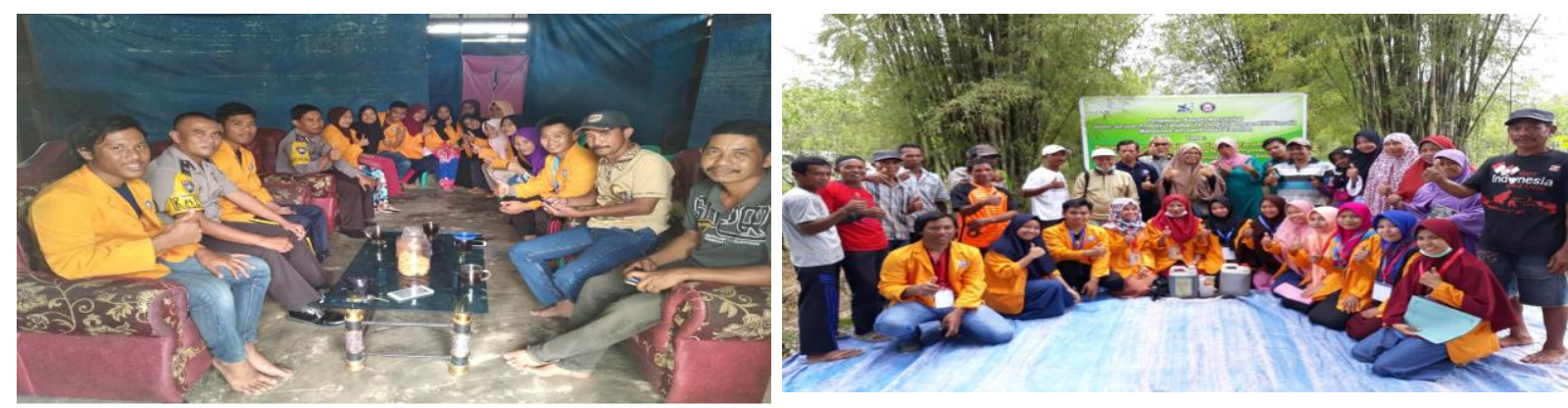

Gambar 1: Tim Mensosialisasikan Pestisidan Nabati sebagai Pengendali Hama dan penyakit Tanaman Kakao

\section{Evaluasi Efek Pengabdian Terhadap Perubahan Pengetahuan Masyarakat}

Menjelang berkahirnya kegiatan pengabdian Dosen Terintegrasi KKN Tematik, dilakukan evaluasi pemahaman masyarakat melalui tes keterampilan tentang pembuatan pestisida nabatas dan MOL. Kegiatan dilakukan tes tentang proses pembuatan sampai pada aplikasinya pada tanaman kakao dilakukan pada 73 petani kakao. Sesuai sesuai dengan hasil evaluasi menunjukkan bahwa terjadi peningkatan pemahaman sebelum dan setelah pengabdian dilaksananan, dimana sebelum pengabdian hanya $6 \%$ petani mempunyai keterampilan dan pembuatan pestisida nabati dan 3,48\% dalam pembuatan MOL dan masing-masing meningkat menjadi $24,46 \%$ untuk pembuatan pestisida nabati dan $66,05 \%$ untuk pembuatan MOL setelah pelaksanaan pengadian dilaksanakan, lebih jelasnya dapat disajikan pada gambar 1 dibawh ini:

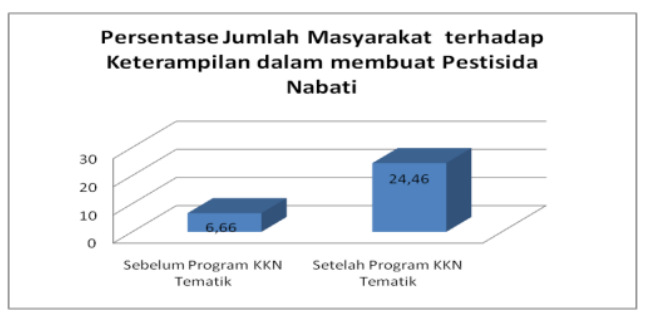

Gambar 2. Perubahan keterampilan dalam pembuatan pestisida nabati

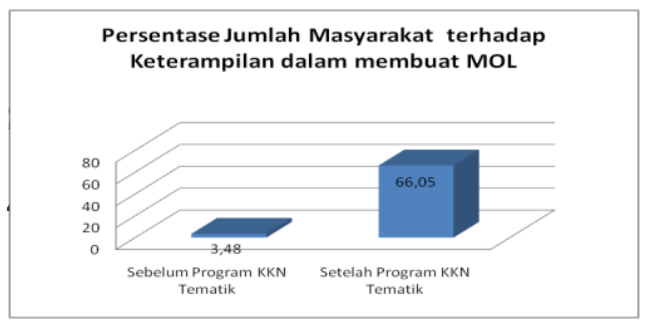

Gambar 3. Perubahan keterampilan dalam pembuatan MOL

\section{SIMPULAN DAN SARAN}

Berdasarkan hasil analisis situasi dan pelaksanaan pengabdian tentang peningkatan partisipasi dalam pengendalian hama dan penyakit tanaman kakao di Desa Amohalo Kecamatan Konda Kabupaten Konawe Selatan yaitu: (1) Masyarakat belum dimanfaatkan untuk dijadikan pestisida nabati untuk mengendalikan hama dan penyakit pada tanaman perkebunanan; (2) Kegiatan pengabdian dosen terintegrasi KKN Tematik dapat meningkatkan keterampilan petani kakao dalam pembuatan pestisida nabati dan MOL.

Adapun saran dalam penelitian ini adalah (1) Dalam meningkatkan partisipasi masyarakat guna memanfaatkan bahan alam sebagai pengendali hama dan penyakit tanaman kakao diperlukan pendampingan dari lembaga terkait; (2) Diperlukan penyuluhan yang intensif agar masyarakat lebih mengacu kepada penggunaan pestisida nabati dalam bidang pertanian. Karena dengan penggunaan pestisida kimia secara berlebihan dan tidak selektif akan meningkatkan residu pestisida sehingga mengganggu kesehatan masyarakat dan merusak ekosistem.

\section{DAFTAR RUJUKAN}

Alwi, L. 2018. Pemetaan Sosial Ekonomi Petani, di Kabupaten Konawe Selatan. Penelitian Kerjasama Antara Badan Penelitian dan Pengembangan Daerah Kabupaten Konawe Selatan dengan Lembaga Penelitian dan Pengabdian Kepada Masyarakat Universitas Halu Oleo, Kendari

Ardana.I.K., Karmawati dan W. Rumini. 2010. Pengendalian hama tanaman perkebunan dengan biopestisida jarak 
pagar. Prosiding Seminar Nasional Inovasi Perkebunan 2010, Jakarta, 1214 November 2010 h. 67-71.

Birgit Kerstan, 1995. Gender-Specifict Partiicipatory Approach; a Trainer Manual. CTC-Jernan.

Karmawati, E. 2010. Pengendalian hama Helopeltis spp pada tanaman jambu meteberdasarkan ekologi; Strategi dan implementasinya.Pengembangan Inovasi Pertanian 3 (2) : 102-119.

Lim, G.T. 1992. Biology, ecology, and control ofcocoa podborer Conopomorpha cramerella (Snellen). In: Keane P.J. Putter CAJ.Editors. Cocoa Pest and Disease Management in Southeast Asia andAustralasia. FAO Plant Production andProtection Paper. Pp. 85-100.
Lyra Srinivasan, 1990. Tools for Community Participation; A Manual for Training Trainers in Participatory Techniques, PROWWES/UNDP.

Madry, B. 1994. Perkembangan hama penggerekbuah kakao PBK dan upayapenanggulangannya di Indonesia. GelarTeknologi Regional Pengendalian HamaKakao. Polmas, Sulsel.

Pakih, J.S. 1999. Penggunaan pestisida nabatidalam upaya penerapan pengendalianhana terpadu (PHT) organismepengganggu tanaman (OPT)perkebunan di Jawa Barat. DalamProsiding Forum Komunikasi IlmiahPemanfaatan Pestisida Nabati, Bogor 9-10 Nopember. Pusat Penelitian TanamanPerkebunan, Bogor, hal 337347 